\title{
Effect of cell-surface components and metabolites of lactic acid bacteria and probiotic organisms on cytokine production and induction of CD25 expression in human peripheral mononuclear cells
}

\author{
R. Ashraf, ${ }^{*}$ T. Vasiljevic, ${ }^{\star}$ S. C. Smith,† and O. N. Donkor ${ }^{* 1}$ \\ *Advanced Food Systems Research Unit, College of Health and Biomedicine, Victoria University, Werribee Campus, PO Box 14428, \\ Melbourne 8001, Australia \\ †School of Exercise and Nutrition Sciences, Faculty of Health, Gut Health SRC Molecular and Medical Research, Deakin University, Burwood, \\ Victoria 3125, Australia
}

\section{ABSTRACT}

In the current study, the relative contribution of cellsurface components (CSC) and cell-free supernatants (CFS) in the immuno-modulatory properties of 17 strains of probiotic and lactic acid bacteria (LAB) was assessed. The production of pro- and antiinflammatory cytokines including IL-2, IL-4, IL-10, IL-12 p70, IFN- $\gamma$, tumor necrosis factor- $\alpha$ (TNF- $\alpha)$, and transforming growth factor- $\beta$ was measured at different time points after stimulation of buffy coat derived-peripheral blood mononuclear cells (PBMC) from healthy donors with CSC and CFS of probiotic and LAB. Results showed that CSC of probiotic and LAB strains induced production of $\mathrm{T}$ helper 1 and 2 type cytokines. Transforming growth factor- $\beta$ was stimulated at highest concentrations, followed by IL-10 and TNF- $\alpha$. The CFS of all tested bacterial strains induced PBMC for significantly high levels of IL-10 secretion compared with unstimulated cells, but the values were less than lipopolysaccharide-stimulated cells. Cytokines due to CFS stimulation showed declined concentration for IL-2, TNF- $\alpha$, and IL-4, and complete disappearance of IL- 12 , IFN- $\gamma$, and transforming growth factor- $\beta$ in the cultured medium at $96 \mathrm{~h}$ of incubation. Results of cytokine data demonstrate proinflammatory $\mathrm{TNF}-\alpha$ immune responses are mainly directed through cell-surface structures of probiotic and LAB, but antiinflammatory immune responses are mediated both by metabolites and cell-surfaces of these bacteria. The induction of $\mathrm{CD} 4{ }^{+} \mathrm{CD} 25^{+}$regulatory $\mathrm{T}$ cells after stimulation of PBMC with CSC and CFS of probiotic and LAB showed regulatory $\mathrm{T}$ cell activity appeared to be influenced both by the CSC and metabolites, but was principally triggered by cell surfaces of probiotic and LAB strains.

Key words: probiotic bacteria, cell-surface component, cell-free culture supernatant, regulatory T-cell

Received September 5, 2013.

Accepted January 7, 2014.

${ }^{1}$ Corresponding author: Osaana.Donkor@vu.edu.au

\section{INTRODUCTION}

Probiotic foods are growing in popularity as foods containing live microorganisms that actively improve health by maintaining the balance of gut microflora and aiding in the treatment or prevention of some diseases. Many strains of lactic acid bacteria (LAB) are believed to have probiotic properties and offer various health benefits. Lactobacillus and Bifidobacterium strains used as probiotics have been well recognized for their role in preventing and treating acute gastrointestinal infections, diarrhea, allergy, atopic diseases, and inflammatory bowel diseases (Van Niel et al., 2002; Clancy, 2003; Isolauri, 2004; Wickens et al., 2008; Ryan et al., 2009). The beneficial health effects of these strains are based primarily on their ability to regulate differentially the production of anti- and proinflammatory cytokines and the $\mathrm{T}$ helper (Th) 1 and Th2 balance. The immune responses classified as Th1 produce proinflammatory cytokines and are involved in cellular immunity against intracellular infections. The Th2-type responses produce variety of antiinflammatory cytokines and promote humoral immunity against extracellular pathogens. Live probiotic bacteria are capable of inducing enhanced mucin expression, phagocytosis, and different profiles of cytokines (Mattar et al., 2002; Shida et al., 2006; Caballero-Franco et al., 2007; Suzuki et al., 2008; Kaji et al., 2010; Donkor et al., 2012). Induction of cytokines by probiotic and LAB indicates that these bacteria can stimulate immune responses and the effects can be exerted directly or indirectly. Although, mechanisms of these immunological responses are still not clear, it can be comprehended that different bacterial cell components and metabolites may account for the differences in immunological responses. These immunological effects in terms of cytokine production have been observed in in vitro and murine models by probiotic cell components, including peptidoglycan, cell wall, LPS, and DNA (Erickson and Hubbard, 2000; Lammers et al., 2003; Hessle et al., 2005; Matsumoto et al., 2005, 2009; Medina et al., 2007). Many components 
of bacterial cell wall, such as LPS, peptidoglycans, and lipoteichoic acids, have shown to be involved in indirect stimulation of immune cells for cytokine production. Several conserved components of the bacterial cell wall have been shown to bind to receptors on the cell surface of monocytes and macrophages and induce the production of proinflammatory cytokines (Underhill, 2003). It is stipulated that the cell wall components may activate macrophages, endothelial cells, smooth muscle cells, and neutrophils and, in turn, release some mediators. Mediators, such as tumor necrosis factor (TNF)- $\alpha$, IL-1, IL-6, IL-8, IL-12, elastases and cathepsin, prostaglandins, as well as reactive oxygen and nitrogen species, may be produced (Erickson and Hubbard, 2000; Hessle et al., 2005). Little is known about the precise mechanisms by which lactobacilli exert beneficial effects, but it is believed that it works through activation of innate immune system that recognizes conserved microbial structures by use of pattern recognition receptors, such as toll-like receptors, whose ligands may be gram-positive or -negative cell wall structures (Dogi et al., 2010). These structures have shown to induce immune response in several in vivo and in vitro experimental models (Wang et al., 2003).

The antiinflammatory cytokines transforming growth factor (TGF)- $\beta$ and IL-10 have also been implicated in regulatory $\mathrm{T}$ cell (Treg) function. The Treg are developmentally classified into natural, induced, or adaptive populations. The normal immune system endogenously produces normal cellular constituents of $\mathrm{CD} 4^{+} \mathrm{T}$ cell population that play a central role in immune protection. Most natural $\mathrm{CD}^{+}$Treg constitutively express CD25 molecule (IL-2 receptor $\alpha$ chain; Sakaguchi, 2005; Lavasani et al., 2010). The $\mathrm{CD} 4^{+} \mathrm{CD} 25^{+}$Treg constitute a specialized subpopulation of $\mathrm{T}$ cells that suppress a range of effector cell types and thereby contribute to the maintenance of immune homeostasis (Sakaguchi et al., 1995). In vitro, $\mathrm{CD} 4^{+} \mathrm{CD} 25^{+}$Treg have been shown to suppress the activation and expansion of naïve cells, which require direct contact of regulatory cells with target cells and secretion of the immuno-regulatory cytokines IL-10 and TGF- $\beta$ (von Boehmer, 2005; Fantini et al., 2007; Bollyky et al., 2009; Lavasani et al., 2010). The $\mathrm{CD} 4{ }^{+} \mathrm{CD} 25^{+}$Treg have been shown to suppress the development of autoimmune disease after cotransfer of $\mathrm{CD} 4^{+} \mathrm{CD} 25^{+}$Treg in immuno-deficient recipients. The implication of $\mathrm{CD} 4^{+} \mathrm{CD} 25^{+} \mathrm{T}$ cells in the inhibition of development of autoimmune diseases could appear to be both a cytokine-dependent and -independent process (Asseman et al., 1999; Seddon and Mason, 1999; McHugh et al., 2001, 2002).

Our previous study and earlier research conducted in our laboratory established that probiotic strains differ in their ability to induce the production of proinflam- matory cytokines, including IFN- $\gamma$, IL- 12, TNF- $\alpha$, and IL-2, and antiinflammatory cytokines, such as IL-10, IL- 4 and TGF- $\beta$. Moreover, strain differences exist in inducing Treg population revealed by the induction of CD25 and FoxP3 expression in stimulated peripheral blood mononuclear cells (PBMC; Donkor et al., 2012). The strain differences and variations in immune responses called for further detailed studies by focusing on cell free supernatants of probiotic bacteria before future in vivo experiments. The current study, therefore, investigated the cytokine profile and induction of $\mathrm{CD}^{+} \mathrm{CD} 25^{+}$regulatory $\mathrm{T}$ cells after stimulation of PBMC with structural cell components and metabolites of 17 strains of LAB and probiotic organisms. This will help determine the relative contribution and importance of structural components or extracellularsecreted molecules of $\mathrm{LAB}$ and probiotic strains to overall immuno-modulatory activity of these strains. Moreover, it will also assist us in understanding the involvement of these cell fractions in the differentiation of Th cell subsets and induction of regulatory $\mathrm{T}$ cell population.

\section{MATERIALS AND METHODS}

\section{Bacterial Strains and Enumeration of Bacterial Cells}

Pure cultures of Lactobacillus bulgaricus ssp. delbrueckii 11842, Streptococcus thermophilus M5, Lactococcus lactis R704, Bifidobacterium lactis BB12 were provided by Chr. Hansen (Chr. Hansen Pty. Ltd., Bayswater, Australia) and Lactobacillus paracasei 292, Lactobacillus salivarius 5248, Lactobacillus reuteri, Lactobacillus rhamnosus G5434, Lactobacillus acidophilus 2401, Lb. acidophilus 388, Lactobacillus plantarum 276, Lb. rhamnosus 5434, Lc. lactis, S. thermophilus 1342, Lactobacillus casei 290, Bifidobacterium breve BB99, and Bifidobacterium longum 1941 were obtained from Victoria University Culture Collection (Werribee, Victoria, Australia). The parent stock cultures were kept at $-80^{\circ} \mathrm{C}$ in PBS containing $40 \%$ glycerol, whereas lyophilized cultures were retained at $-20^{\circ} \mathrm{C}$ in a freezer. Prior to the experiment, the cultures were activated in de Man, Rogosa, and Sharpe (MRS) broth (Oxoid, Melbourne, Australia) at $37^{\circ} \mathrm{C}$ for $18 \mathrm{~h}$ and samples were removed for Gram staining to check for purity and bacterial morphology. Bacteria were further grown on MRS agar (1.5\% wt/vol agar) as a reference medium to observe the colonial characteristics.

The bacterial cell concentration was standardized by enumeration as colony-forming units per milliliter using the pour-plate technique. Briefly, bacteriological peptone solution was used as diluent for the enumeration experiment and it was prepared by dissolving $0.15 \%$ 
(wt/vol) bacteriological peptone (Oxoid) in milli-Q water. The $\mathrm{pH}$ of diluent was adjusted to $7.0 \pm 0.2$, dispensed in McCartney bottles (Labtek Laboratory Glassware Agencies, Brendale, QLD, Australia) in 9-mL aliquots, followed by autoclaving at $121^{\circ} \mathrm{C}$ for $15 \mathrm{~min}$. For enumeration of bacterial cell number, $1 \mathrm{~mL}$ of each freshly prepared culture was 10-fold serially diluted and plated onto MRS agar (for bifidobacteria, supplemented with $0.05 \%$ L-Cys $\mathrm{HCl}$ ). For bifidobacteria and lactobacilli cultures, incubations were performed at $37^{\circ} \mathrm{C}$ for $72 \mathrm{~h}$ anaerobically using anerobic gas generating kits (Oxoid) in anerobic jars; conversely, Lactococcus and Streptococcus strains were incubated at $37^{\circ} \mathrm{C}$ for $24 \mathrm{~h}$ aerobically.

\section{Extraction of Cell-Surface Components}

The cultures were activated successively 3 times in MRS broth (Oxoid), at $37^{\circ} \mathrm{C}$ for $18 \mathrm{~h}$ with a $1 \%$ inoculum transfer rate. All media were sterilized by autoclaving at $121^{\circ} \mathrm{C}$ for $15 \mathrm{~min}$. For bifidobacteria, media were supplemented with membrane-filtered $0.05 \%$ L-Cys HCl (Sigma-Aldrich, St. Louis, MO) to provide an anaerobic condition and to facilitate their growth. Cells were harvested by centrifugation $(6,000$ $\times g$ for 15 min at $4^{\circ} \mathrm{C}$; Beckman $\mathrm{J} 2 / \mathrm{HS}$ centrifuge, JA-14 rotor, Palo Alto, CA) during the stationary growth phase, washed 2 times in PBS (130 $\mathrm{m} M$ sodium chloride, $10 \mathrm{~m} M$ sodium phosphate, $\mathrm{pH} 7.4$ ), and resuspended in PBS containing $40 \%$ glycerol. The cell suspensions were adjusted to $1 \times 10^{6} \mathrm{cfu} / \mathrm{mL}$ and were subjected to 5 sonication cycles at $100 \mathrm{~W}$ output for 15 min each with 2-min intervals on ice, using a probe sonicator (Braun Biotech Inc., Allentown, PA). Cell debris was separated by centrifugation $(10,000 \times$ $g$ for 10 min at $4^{\circ} \mathrm{C}$; Beckman) and the supernatants were collected and standardized for protein concentration. The protein content of surface protein fractions was determined by the Bradford method using total protein kit (Sigma-Aldrich) and BSA (Sigma-Aldrich) as a standard, according to the manufacturer's procedure. The samples of cell-surface components of all 17 bacteria were standardized to $4 \mathrm{mg} / \mathrm{mL}$ of protein concentrations, aliquoted, and stored at $-80^{\circ} \mathrm{C}$ until used. The absence of viability losses was confirmed by plate counting as described above.

\section{Preparation of Cell-Free Culture Supernatants}

To obtain cell-free culture supernatants, the spent MRS media (from where the cells were harvested), were filter-sterilized $(0.45-\mu \mathrm{m}$ pore size filter, Millipore, Billerica, MA) to eliminate the possible presence of viable cells. The supernatants were adjusted to $\mathrm{pH} 7.2$ with 1
$M \mathrm{NaOH} ; \mathrm{MRS}$ media without any inoculation was used as a control. Aliquots of cell-free culture supernatants samples were kept at $-80^{\circ} \mathrm{C}$ until use. Viability test was performed after storage to exclude the chances of any contamination or the presence of any viable cells. A fresh aliquot of each sample was thawed for every new experiment to avoid variability in the samples between experiments.

\section{Isolation of Human PBMC}

Human PBMC were isolated from buffy coats (Australian Red Cross Blood Services, Melbourne, Australia). The proposed research project was accepted and deemed to meet the requirements of the National Health and Medical Research Council "National Statement on Ethical Conduct in Human Research" (National Health and Medical Research Council, 2007) by the Chair of the Faculty of Health, Engineering, and Science, Victoria University Human Research Ethics Committee. Contract agreement was made with Australian Red Cross Blood Services Melbourne Australia, for the supply of buffy coat. The PBMC were isolated from individual buffy coat $(60 \mathrm{~mL})$ by centrifugation over a Ficoll-Paque Plus (GE Healthcare Pty Ltd., Silverwater, NSW, Australia) gradient. Briefly, buffy coats were diluted with an equal volume of $1 \times$ PBS that was freshly prepared from $10 \times$ PBS, pH 7.4 (Invitrogen Pty Ltd., Mount Waverly, Victoria, Australia), and layered on Ficoll-Paque Plus. Cells at the interphase were collected following centrifugation $\left(400 \times g\right.$ for $30 \mathrm{~min}$ at $18^{\circ} \mathrm{C}$, no brake; Sorvall RT7 centrifuge, DuPont, Newtown, CT). The separated layers of PBMC were washed once in RPMI-1640 (Invitrogen) following centrifugation $\left(400 \times g\right.$ at $18^{\circ} \mathrm{C}$ for 10 min, no brake; Sorvall). The pellet was resuspended in $2 \mathrm{~mL}$ of ammonium-chloride-potassium (ACK) lysing buffer (Invitrogen) and incubated for $2 \mathrm{~min}$ at room temperature. The volume was then adjusted to $30 \mathrm{~mL}$ using sterile PBS and centrifuged $(250 \times$ $g$ for $10 \mathrm{~min}$ at $4^{\circ} \mathrm{C}$, no brake; Sorvall). Following 2 subsequent washes with RPMI-1640, the volume was adjusted to $3 \times 10^{6}$ cells $/ \mathrm{mL}$ in RPMI-1640, supplemented with $10 \%$ FBS, qualified, and heat inactivated (Invitrogen) with $100 \mathrm{mg} / \mathrm{mL}$ of streptomycin (SigmaAldrich) and $100 \mathrm{U} / \mathrm{mL}$ of penicillin (Sigma-Aldrich). The leftover cells were frozen at $-80^{\circ} \mathrm{C}$ in a Nalgene Mr. Frosty Freezing Container (Thermo Fisher Scientific Pty Ltd., Scoresby, Victoria, Australia), followed by transferring in liquid nitrogen. For freezing, the cells were resuspended in freeze mix $(90 \%$ FBS $+10 \%$ dimethyl sulfoxide; Sigma-Aldrich) at $2.5 \times 10^{7}$ cells/ $\mathrm{mL}$ in aliquots of $1.5 \mathrm{~mL}$ per cryotube (Corning Inc., Clayton, Victoria, Australia). 


\section{Stimulation of PBMC}

For the stimulation steps, PBMC were incubated in 24-well flat-bottomed polystyrene microtiter plates (Sigma-Aldrich) with a final concentration of $1 \times 10^{6}$ cells $/ \mathrm{mL}$ in the presence or absence of different stimulants at $37^{\circ} \mathrm{C}$ in $5 \% \mathrm{CO}_{2}$ for different time slots. Final concentrations of $50 \mu \mathrm{L} / \mathrm{mL}$ of bacterial cell-free culture supernatant and $100 \mu \mathrm{g} / \mathrm{mL}$ of crude cell-surface component samples were used as stimulants. Purified LPS from Escherichia coli O111:B4 (Sigma-Aldrich) and concanavalin A from Canavalia A (Sigma-Aldrich) were used to stimulate PBMC at a concentration of 1 and $5 \mu \mathrm{g} / \mathrm{mL}$, respectively, as positive controls. Nonstimulated PBMC were also evaluated as controls of basal cytokine production. Supernatants of stimulated and nonstimulated PBMC were collected at 24, 48, 72, and $96 \mathrm{~h}$ by centrifugation, fractionated in aliquots, and stored at $-20^{\circ} \mathrm{C}$ until cytokines were analyzed.

\section{Cytokine Assays}

Cytokine concentrations of supernatants were measured by ELISA using BD OptEIA ELISA Sets (BD Bioscience, San Diego, CA), including IL-2, IL-4, IL-10, IL-12 (p70), IFN- $\gamma$, TNF- $\alpha$, and TGF- $\beta$. The detection procedures were performed according to the manufacturer's instructions. Data are expressed as the mean cytokine response minus background $(\mathrm{pg} / \mathrm{mL})$ of each treatment from triplicate wells, plus or minus the standard error of the mean.

\section{Cell Staining and Flow Cytometry Analysis}

For staining purposes, PBMC $\left(10^{6}\right.$ cells $)$ were cocultured with samples of $50 \mu \mathrm{L} / \mathrm{mL}$ of cell-free culture supernatants, $100 \mu \mathrm{g} / \mathrm{mL}$ of crude cell-surface components, $1 \mathrm{mg} / \mathrm{mL}$ of LPS (Sigma-Aldrich) or media alone, in a 24 -well plate at $37^{\circ} \mathrm{C}$ in $5 \% \mathrm{CO}_{2}$ for 96 $\mathrm{h}$. After incubation, cells were washed twice using fluorescence-activated cell sorter (FACS) buffer (PBS $+2 \%$ FACS $)$ and centrifuged at $500 \times g$ for $10 \mathrm{~min}$. According to the manufacturer's instructions, PBMC were resuspended at $10^{6}$ cells $/ \mathrm{mL}$, stained with fluorescent dye-conjugated antibodies, using fluorescein isothiocynate-labeled anti-human CD4, allophycocyanin-labeled anti-human CD25 (BD Bioscience), and peridinin chlorophyll protein-labeled antihuman CD3 (Biolegend, San Diego, CA). Samples were analyzed using a BD FACS Calibur, data were acquired using Cell Quest program (BD Biosciences), and analysis of acquired data was performed using Flowlogic software (Inivai, Mentone, Victoria, Australia) for percent positive cells and expression levels of gated cells. Expres- sion of CD25 on T lymphocyte population was evaluated by gating on $\mathrm{CD}^{+} \mathrm{CD}^{+}$cells and graphed for CD25 expression.

\section{Statistical Analyses}

Regression analysis was used as a goodness-of-fit measure of linear models. Significant differences between treatments were tested by ANOVA followed by a comparison between treatments performed by Fisher's least significant difference method and multiple range test with a level of significance of $P<0.05$. Data are expressed as mean and standard deviation of triplicate measures determined in 4 independent experiments.

\section{RESULTS}

\section{Cytokine Production by PBMC upon Stimulation with Cell-Surface Components of Probiotic and LAB Strains}

The immuno-modulatory characteristics of cellsurface components of different strains of LAB and probiotic bacteria, in terms of cytokine production at different time points, are shown in Figures 1, 2, and $3 a$ to g. Results show that cell-surface components of probiotic and LAB strains produced Th1- and Th2type cytokine responses, where TGF- $\beta$ was produced in higher concentrations followed by IL-10 and TNF- $\alpha$. Of all proinflammatory cytokines determined, TNF- $\alpha$ was abundantly produced, followed by IL-12, IFN- $\gamma$, and IL-2. Among antiinflammatory cytokines, TGF- $\beta$ had the highest concentration, followed by IL-10 and IL-4. Cell-surface protein fractions of all 17 bacteria induced significantly high levels $(P<0.05)$ of IL-2 at $96 \mathrm{~h}$ and TNF- $\alpha$ at 48 and $96 \mathrm{~h}$ compared with unstimulated cells. The highest yield of TNF- $\alpha$ was found at $48 \mathrm{~h}$ in the range of 414 to $1,164 \mathrm{pg} / \mathrm{mL}$. In addition, the production of TGF- $\beta$ and IL-10 was also induced significantly more $(P<0.01)$ by all treated PBMC than untreated cells. Cell-surface fractions of S. thermophilus 1342, Lb. acidophilus 2401, Lb. rhamnosus G5434, Lb. plantarum 276, B. breve BB99, Lb. rhamnosus 5434, and Lb. salivarius 5248 significantly $(P<0.05)$ increased levels of IL-12 at $72 \mathrm{~h}$ compared with unstimulated cells. Only cell-surface protein fractions of Lb. delbrueckii ssp. bulgaricus 11842 induced IFN- $\gamma$ secretion significantly $(P<0.05)$ greater than LPS-induced or nonstimulated cells. Interestingly, the production of all the tested cytokines was detected at $24 \mathrm{~h}$ of stimulation and reached maximum concentrations at 48 or $72 \mathrm{~h}$ of incubation as opposed to IL-2 and IL-10, for which maximum production was observed at $96 \mathrm{~h}$ of stimulation. 

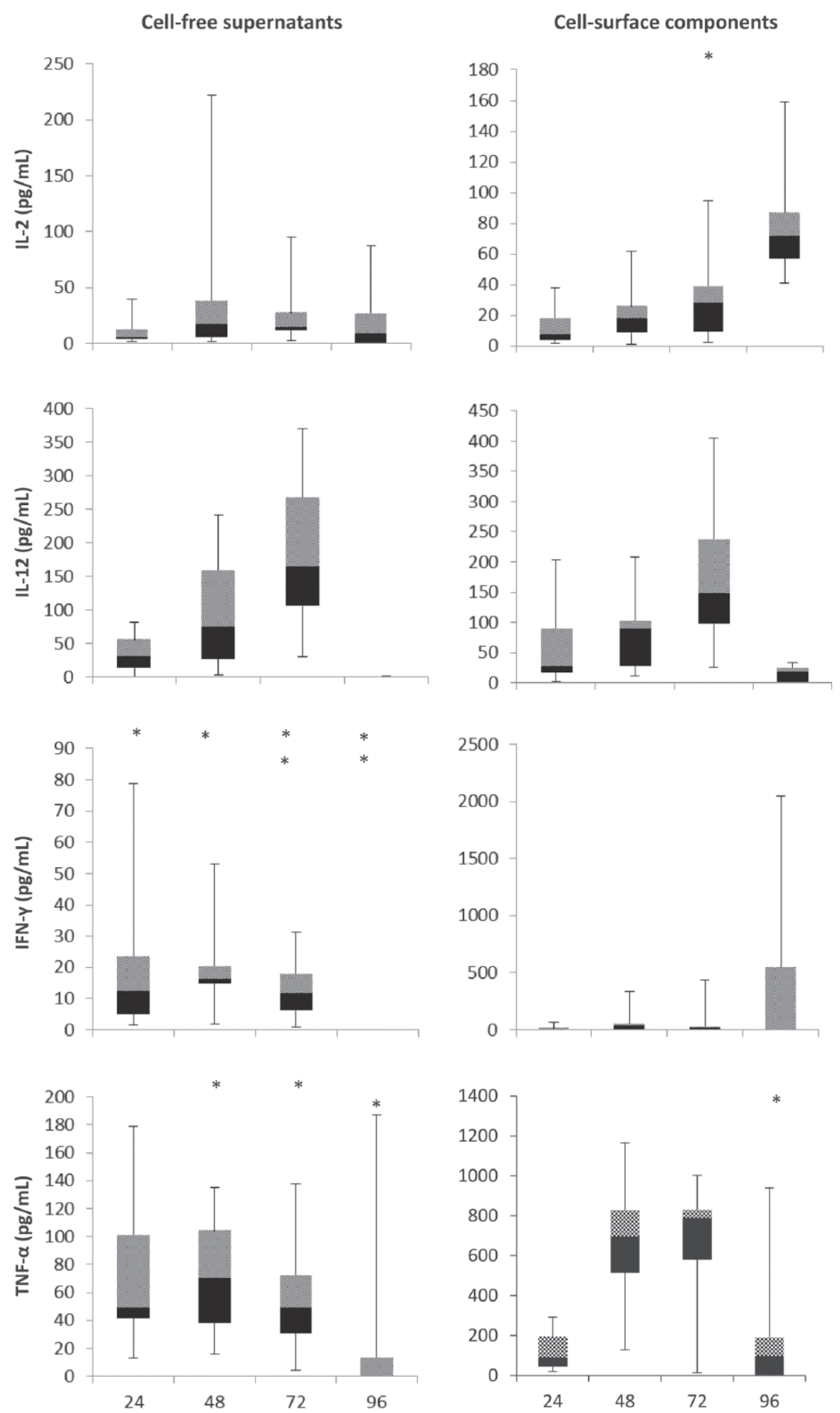

Time for stimulation $(\mathrm{h})$

Figure 1. In vitro production of proinflammatory cytokines IL-2, IL-12, IFN- $\gamma$, and tumor necrosis factor $\alpha$ (TNF- $\alpha$ ) by cell-surface components and cell-free culture supernatants (see Figures 3 and 4 for details). Box plots showing the distribution of each proinflammatory cytokine secreted by peripheral blood mononuclear cells stimulated with cell-surface components and cell-free culture supernatants of 17 lactic acid bacterial strains. The middle of the box shows the median; the upper portion shows the third quartile of the population comprising $25 \%$ more population than the median; the lower portion shows first quartile up to $25 \%$ of population lower than the median; whiskers above and below the bars show maximum and minimum, respectively, of the distribution; and asterisks $(*)$ show outliers. 
Cell free supernatants
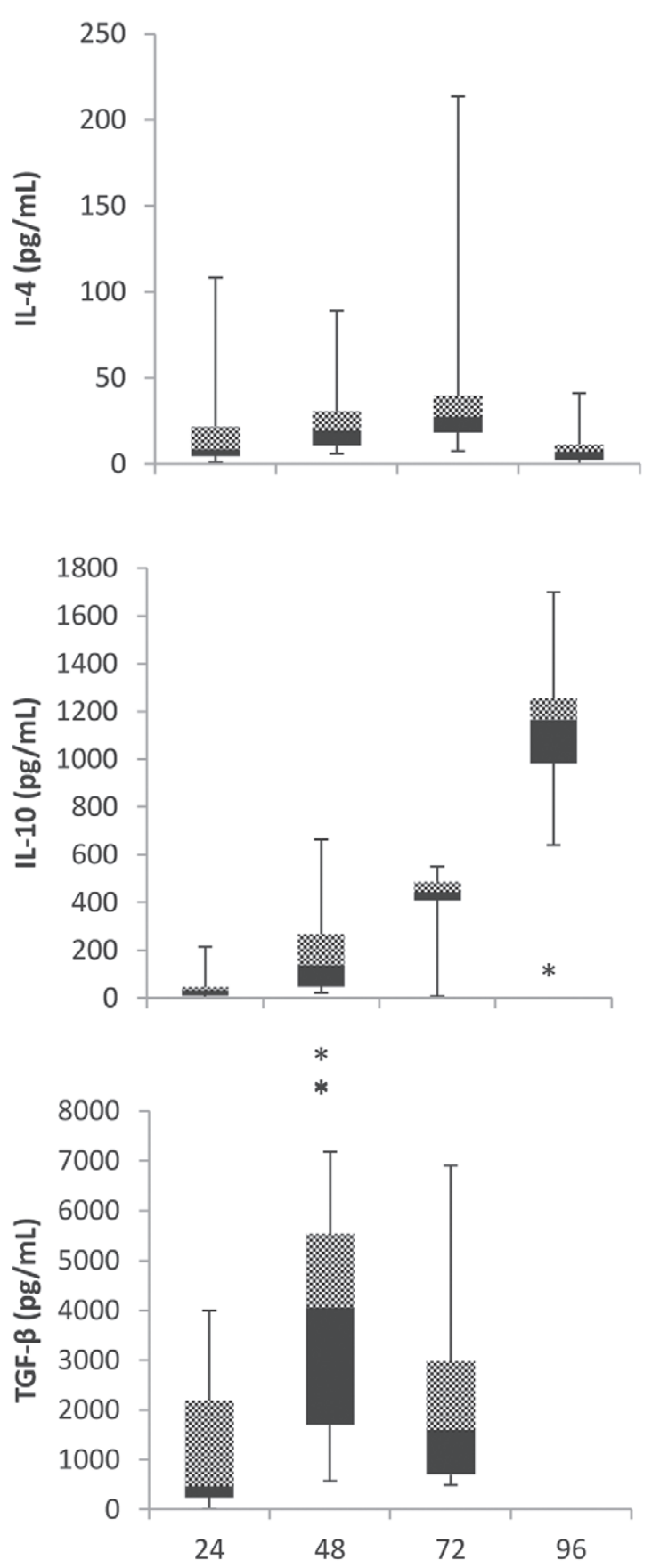

Cell surface components
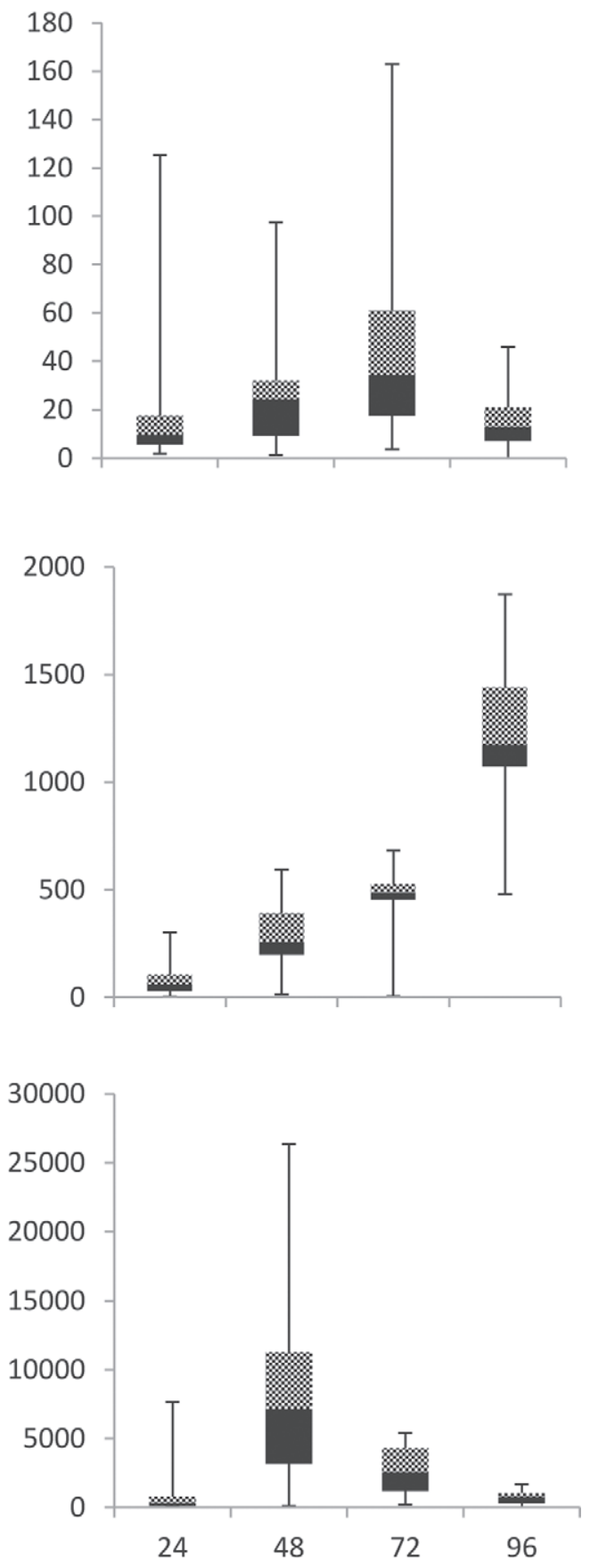

\section{Time for stimulation (h)}

Figure 2. In vitro production of antiinflammatory cytokines IL-4, IL-10, and transforming growth factor $\beta$ (TGF- $\beta$ ) by cell-surface components and cell-free culture supernatants (see Figures 3 and 4 for details). Box plots showing the distribution of each proinflammatory cytokine secreted by peripheral blood mononuclear cells stimulated with cell-surface components and cell-free culture supernatants of 17 lactic acid bacterial strains. The middle of the box shows the median; the upper portion shows the third quartile of the population comprising $25 \%$ more population than median; the lower portion shows the first quartile up to $25 \%$ of population lower than median; whiskers above and below the bars show the maximum and minimum, respectively, of the distribution; and asterisks $(*)$ show outliers. 

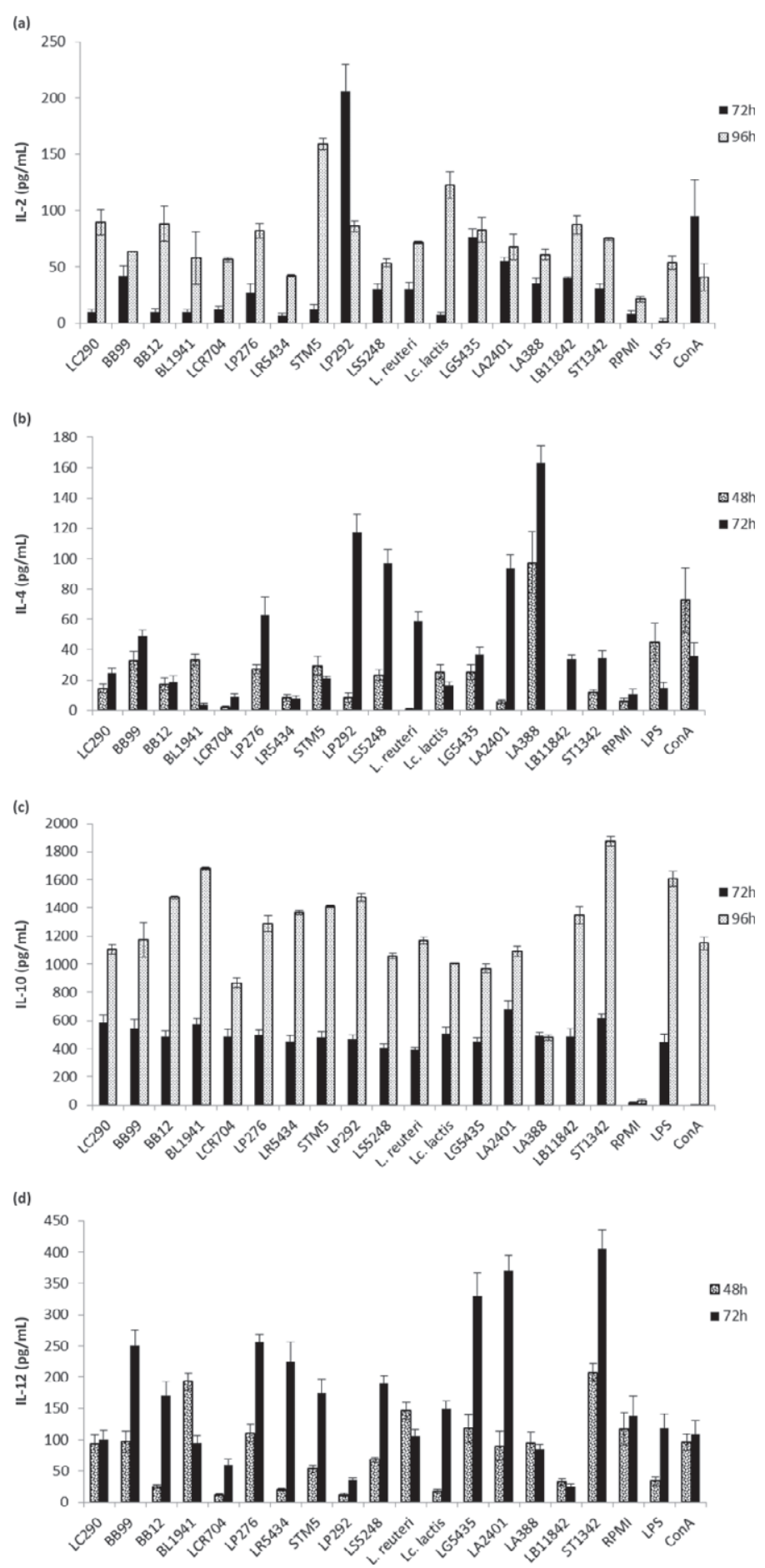

Figure 3. In vitro production of IL-2 (a), IL-4 (b), IL-10 (c), IL-12 (d), IFN- $\gamma$ (e), tumor necrosis factor $\alpha$ (TNF- $\alpha$; f), and transforming growth factor $\beta$ (TGF- $\beta ;$ g). Supernatants of 48-, 72-, and 96-h cocultures of pooled buffy coat-derived peripheral blood mononuclear cells (PBMC) treated with cell-surface components of lactic acid bacterial strains [Lactobacillus casei 290 (LC290), Bifidobacterium breve BB99 (BB99), Bifidobacterium animalis ssp. lactis BB12 (BB12), Bifidobacterium longum 1941 (BL1941), Lactococcus lactis R704 (LCR704), Lactobacillus plantarum 276 (LP276), Lactobacillus rhamnosus 5434 (LR5434), Streptococcus thermophilus M5 (STM5), Lactobacillus paracasei 292 (LP292), Lactobacillus salivarius 5248 (LS5248), Lactobacillus reuteri, Lc. lactis, Lb. rhamnosus G5435 (LG5435), Lactobacillus acidophilus 2401 (LA2401), Lb. acidophilus 388 (LA388), Lactobacillus delbrueckii ssp. bulgaricus 11842 (LB11842), and S. thermophilus 1342 (ST1342)] were collected. The PBMC in Roswell Park Memorial Institute (RPMI) medium alone (nonstimulated PBMC) were evaluated as controls for basal cytokine production. Purified LPS $(1 \mu \mathrm{g} / \mathrm{mL})$ from Escherichia coli O111:B4 and concanavalin A ( $5 \mu \mathrm{g} / \mathrm{mL}$; ConA) from Canavalia A were used as positive controls. The concentration of cytokines was subsequently determined using ELISA kits. Results are expressed as the mean cytokine response $(\mathrm{pg} / \mathrm{mL}) \pm \mathrm{SEM}$ as error bars of each treatment from triplicate wells run as 4 independent experiments. 

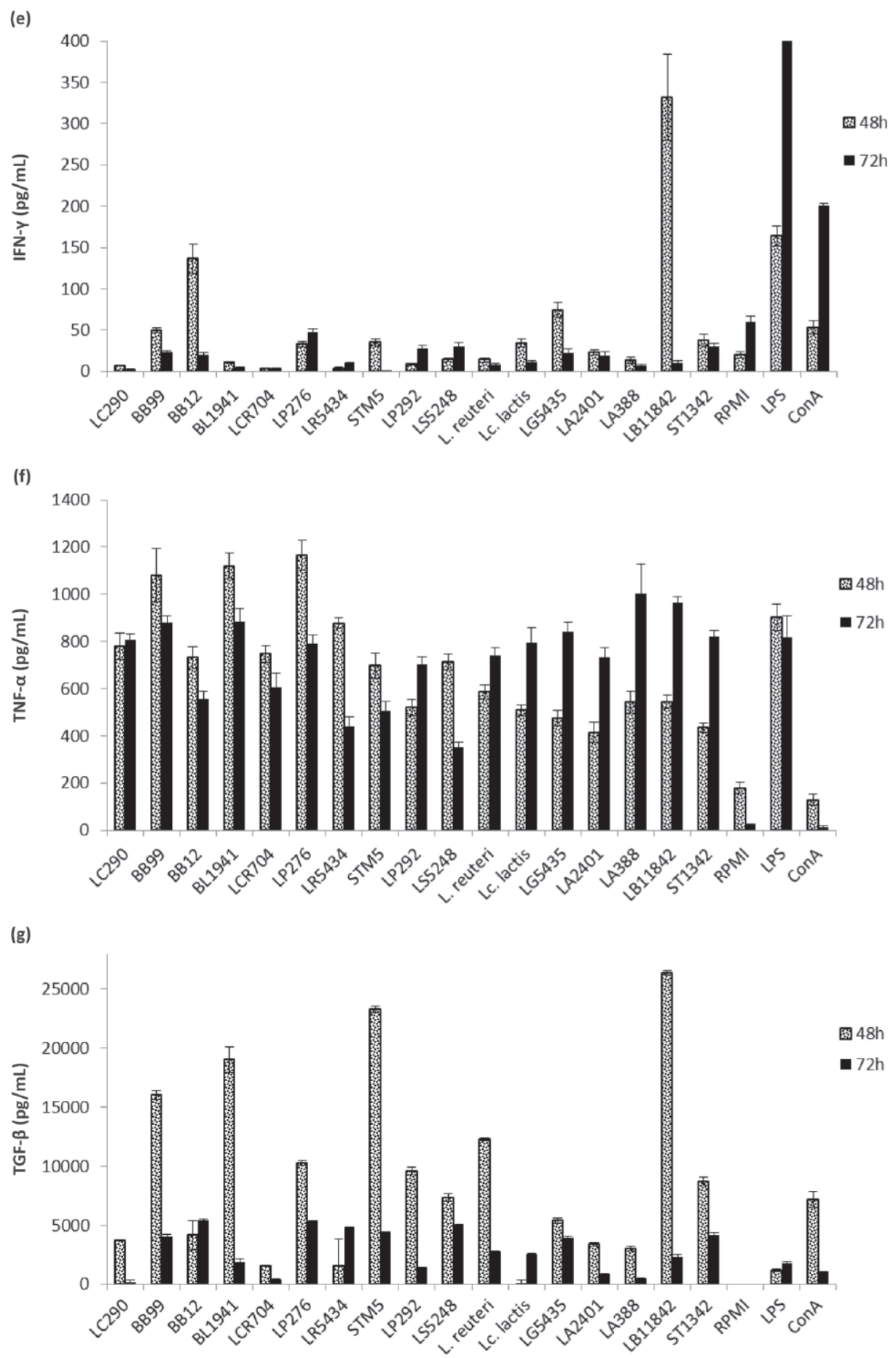

Figure 3 (Continued). In vitro production of IL-2 (a), IL-4 (b), IL-10 (c), IL-12 (d), IFN- $\gamma$ (e), tumor necrosis factor $\alpha$ (TNF- $\alpha$; f), and transforming growth factor $\beta$ (TGF- $\beta ; \mathrm{g}$ ). Supernatants of 48-, 72-, and 96-h cocultures of pooled buffy coat-derived peripheral blood mononuclear cells (PBMC) treated with cell-surface components of lactic acid bacterial strains [Lactobacillus casei 290 (LC290), Bifidobacterium breve BB99 (BB99), Bifidobacterium animalis ssp. lactis BB12 (BB12), Bifidobacterium longum 1941 (BL1941), Lactococcus lactis R704 (LCR704), Lactobacillus plantarum 276 (LP276), Lactobacillus rhamnosus 5434 (LR5434), Streptococcus thermophilus M5 (STM5), Lactobacillus paracasei 292 (LP292), Lactobacillus salivarius 5248 (LS5248), Lactobacillus reuteri, Lc. lactis, Lb. rhamnosus G5435 (LG5435), Lactobacillus acidophilus 2401 (LA2401), Lb. acidophilus 388 (LA388), Lactobacillus delbrueckii ssp. bulgaricus 11842 (LB11842), and S. thermophilus 1342 (ST1342)] were collected. The PBMC in Roswell Park Memorial Institute (RPMI) medium alone (nonstimulated PBMC) were evaluated as controls for basal cytokine production. Purified LPS $(1 \mu \mathrm{g} / \mathrm{mL})$ from Escherichia coli O111:B4 and concanavalin A $(5 \mu \mathrm{g} / \mathrm{mL}$; ConA) from Canavalia A were used as positive controls. The concentration of cytokines was subsequently determined using ELISA kits. Results are expressed as the mean cytokine response $(\mathrm{pg} / \mathrm{mL}) \pm \mathrm{SEM}$ as error bars of each treatment from triplicate wells run as 4 independent experiments. 
(a)

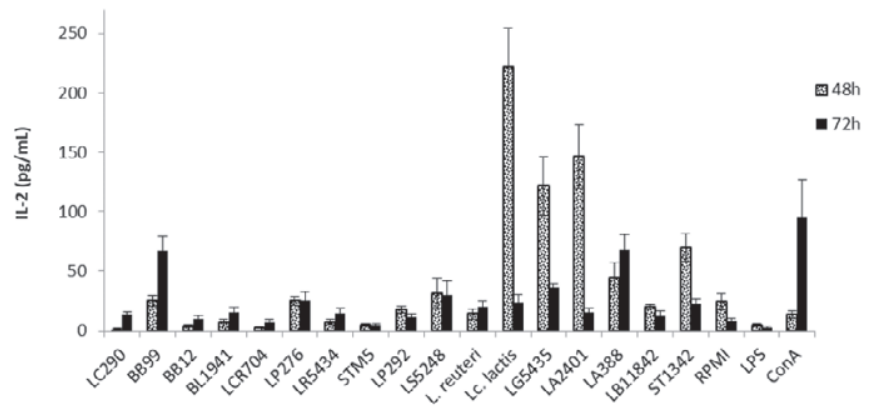

(b)

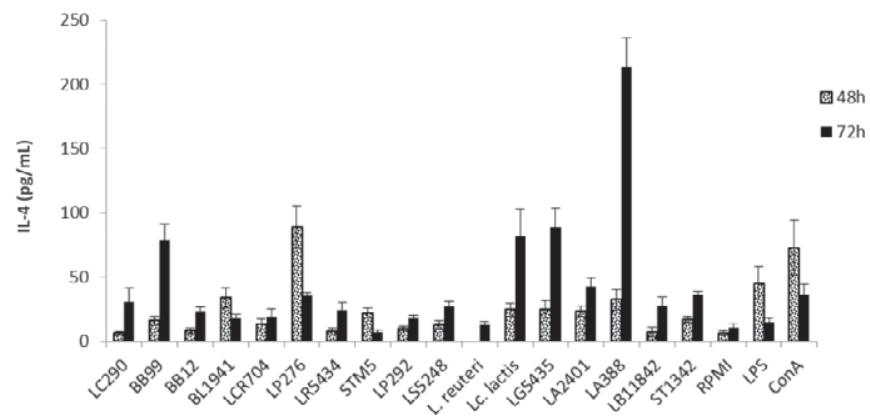

(c)

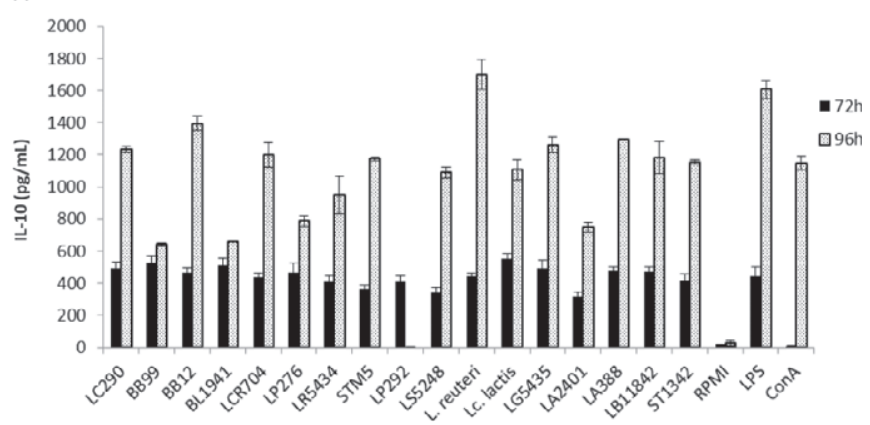

(d)

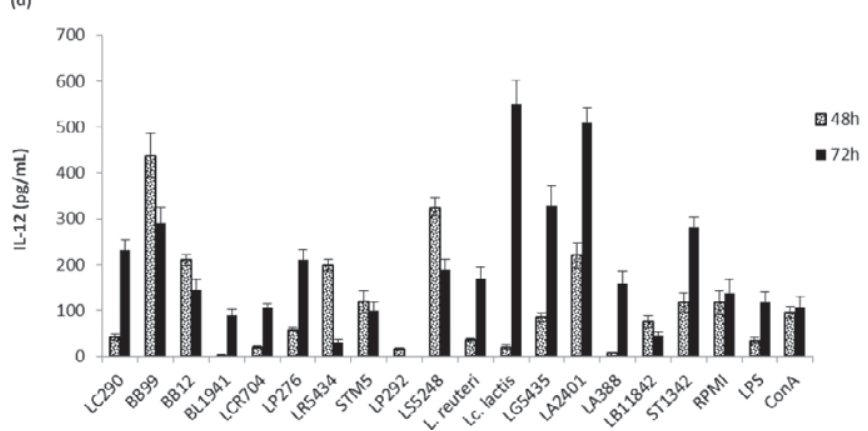

Figure 4. In vitro production of IL-2 (a), IL-4 (b), IL-10 (c), IL-12 (d), IFN- $\gamma$ (e), tumor necrosis factor $\alpha$ (TNF- $\alpha$; f), and transforming growth factor $\beta$ (TGF- $\beta$; g). Supernatants of 24-, 48-, 72-, and 96-h cocultures of pooled buffy coat-derived peripheral blood mononuclear cells (PBMC) treated with cell-free supernatants of 17 strains of lactic acid bacteria [Lactobacillus casei 290 (LC290), Bifidobacterium breve BB99 (BB99), Bifidobacterium animalis ssp. lactis BB12 (BB12), Bifidobacterium longum 1941 (BL1941), Lactococcus lactis R704 (LCR704), Lactobacillus plantarum 276 (LP276), Lactobacillus rhamnosus 5434 (LR5434), Streptococcus thermophilus M5 (STM5), Lactobacillus paracasei 292 (LP292), Lactobacillus salivarius 5248 (LS5248), Lactobacillus reuteri, Lc. lactis, Lb. rhamnosus G5435 (LG5435), Lactobacillus acidophilus 2401 (LA2401), Lb. acidophilus 388 (LA388), Lactobacillus delbrueckii ssp. bulgaricus 11842 (LB11842), and S. thermophilus 1342 (ST1342)] were collected. The PBMC in Roswell Park Memorial Institute (RPMI) medium alone (nonstimulated PBMC) were evaluated as controls for basal cytokine production. Purified LPS $(1 \mu \mathrm{g} / \mathrm{mL})$ from Escherichia coli O111:B4 and concanavalin A $(5 \mu \mathrm{g} / \mathrm{mL}$; ConA) from Canavalia A were used as positive controls. The concentration of cytokines was subsequently determined using ELISA kits. Results are expressed as the mean cytokine response $(\mathrm{pg} / \mathrm{mL}) \pm \mathrm{SEM}$ as error bars of each treatment from triplicate wells run as 4 independent experiments. 

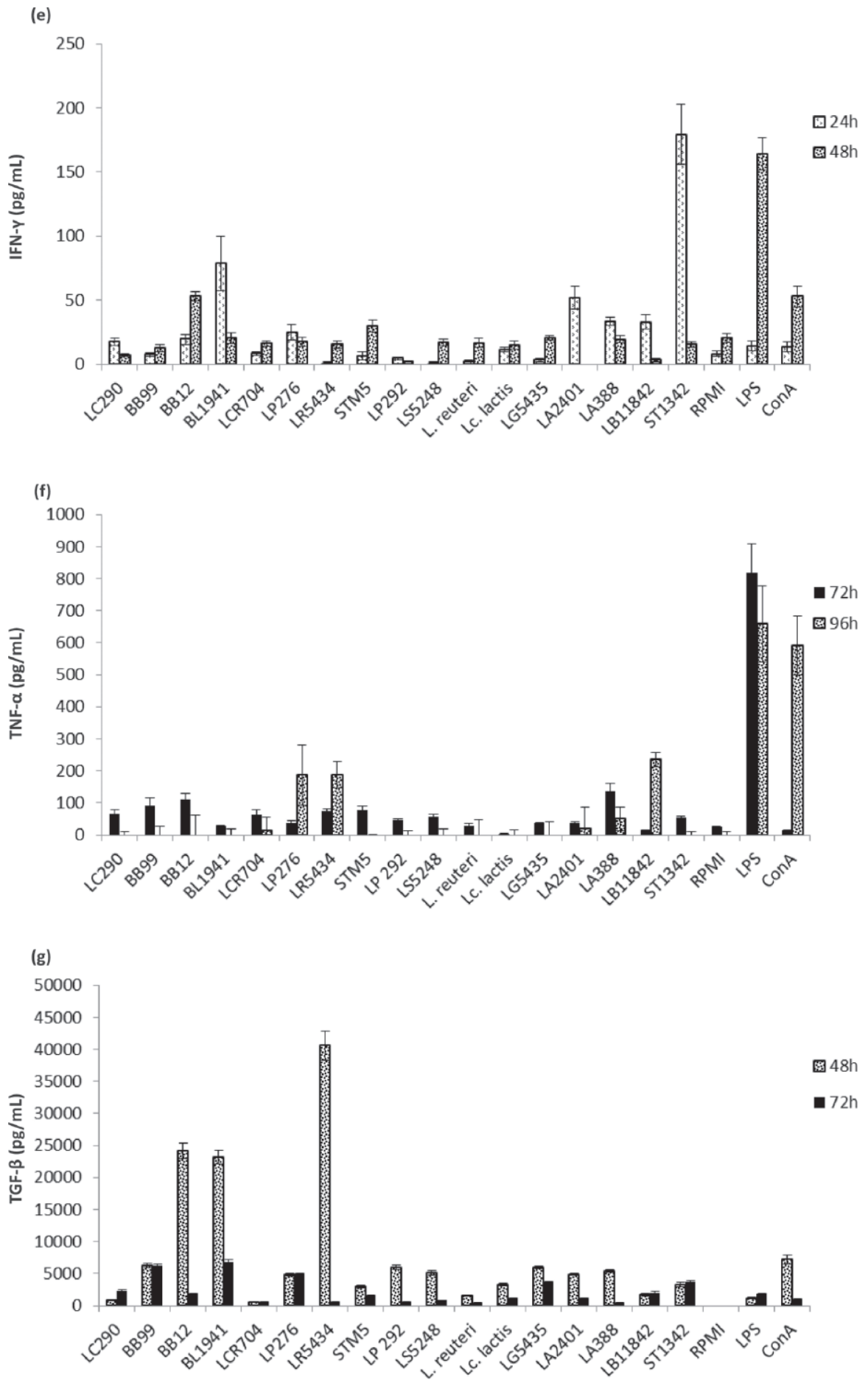

Figure 4 (Continued). In vitro production of IL-2 (a), IL-4 (b), IL-10 (c), IL-12 (d), IFN- $\gamma$ (e), tumor necrosis factor $\alpha$ (TNF- $\alpha$; f), and transforming growth factor $\beta$ (TGF- $\beta$; g). Supernatants of 24-, 48-, 72-, and 96-h cocultures of pooled buffy coat-derived peripheral blood mononuclear cells (PBMC) treated with cell-free supernatants of 17 strains of lactic acid bacteria [Lactobacillus casei 290 (LC290), Bifidobacterium breve BB99 (BB99), Bifidobacterium animalis ssp. lactis BB12 (BB12), Bifidobacterium longum 1941 (BL1941), Lactococcus lactis R704 (LCR704), Lactobacillus plantarum 276 (LP276), Lactobacillus rhamnosus 5434 (LR5434), Streptococcus thermophilus M5 (STM5), Lactobacillus paracasei 292 (LP292), Lactobacillus salivarius 5248 (LS5248), Lactobacillus reuteri, Lc. lactis, Lb. rhamnosus G5435 (LG5435), Lactobacillus acidophilus 2401 (LA2401), Lb. acidophilus 388 (LA388), Lactobacillus delbrueckii ssp. bulgaricus 11842 (LB11842), and S. thermophilus 1342 (ST1342)] were collected. The PBMC in Roswell Park Memorial Institute (RPMI) medium alone (nonstimulated PBMC) were evaluated as controls for basal cytokine production. Purified LPS $(1 \mu \mathrm{g} / \mathrm{mL})$ from Escherichia coli O111:B4 and concanavalin A (5 $\mu \mathrm{g} / \mathrm{mL}$; ConA) from Canavalia A were used as positive controls. The concentration of cytokines was subsequently determined using ELISA kits. Results are expressed as the mean cytokine response $(\mathrm{pg} / \mathrm{mL}) \pm \mathrm{SEM}$ as error bars of each treatment from triplicate wells run as 4 independent experiments. 


\section{Cytokine Production by PBMC upon Stimulation with Cell-Free Supernatants of Probiotic and $L A B$ Strains}

The effects of cell-free extracts of probiotic and LAB strains on cytokine production at different time intervals are shown in Figures 1, 2, and 4a to g. The production of Th1-type cytokine IFN- $\gamma$ and TNF- $\alpha$ were induced by PBMC stimulated with cell-free culture supernatants in significantly $(P<0.05)$ low quantities compared with PBMC stimulated with live strains (data not shown) and cell-surface components of tested strains. Moreover, cell-free culture supernatants of all tested bacterial strains induced PBMC for significant production $(P<0.05)$ of the Th2-type cytokine IL-10 compared with unstimulated cells, but less than LPSstimulated cells. The pattern of IL-10 production for cell-surface components of probiotic and LAB strains found was similar to PBMC stimulated with same live strains (data not shown). Cell-free culture supernatants of Lc. lactis, Lb. acidophilus 2401, Lb. rhamnosus G5434, S. thermophilus 1342, and Lb. acidophilus 388 also induced significantly high levels $(P<0.05)$ of IL-2. Compared with unstimulated PBMC, cell-free culture supernatants of $L b$. delbrueckii ssp. bulgaricus stimulated significantly high $(P<0.05)$ TNF- $\alpha$ production at $96 \mathrm{~h}$, followed by $L b$. plantarum 276 and Lb. rhamnosus 5434. The highest yield of IL-12 was obtained at $72 \mathrm{~h}$ of stimulation, where cell-free culture supernatants of Lc. lactis induced significantly higher $(P<0.05)$ of IL-12 compared with controls, followed by $L b$. acidophilus $2401, L b$. rhamnosus $\mathrm{G} 5434, B$. breve 99, S. thermophilus 1342, Lb. casei 290, Lb. plantarum 276, Lb. salivarius 5248 and $L b$. reuteri. Results in the current study are in line with a previous report (Medina et al., 2007), in which the metabolites secreted into the external medium were not much involved in proinflammatory responses but share antiinflammatory responses of LAB and probiotic strains.

\section{Induction of CD25 Expression in PBMC by Cell-Surface Components of Probiotic and LAB Strains}

Regulatory $\mathrm{T}$ cell induction based on expression of CD25 activation marker in PBMC from a healthy donor was assessed following $96 \mathrm{~h}$ of treatment with crude cell-surface components of 17 bacteria, controls, and LPS-treated cells. The percentages of CD $4^{+} \mathrm{CD} 25+$ lymphocyte cells and representative FACS plots for CD25 expression obtained for cell-surface structures and LPS- treated and untreated PMBC are shown in Figures 5a and b. Data suggested that the number of $\mathrm{CD}^{+} \mathrm{T}$ cells expressing CD25 cells increased sig- nificantly $(P<0.05)$ in stimulated PMBC compared with control. Among the cell-surface protein fraction of tested bacterial cultures, CD25 expression was found significantly $(P<0.01)$ high for the samples of $S$. thermophilus 1342 , followed by $L b$. casei $290, L b$. paracasei 292, S. thermophilus M5, Lb. delbrueckii ssp. bulgaricus 11842, B. lactis BB12, Lb. rhamnosus G5434, Lb. rhamnosus 5434, and Lc. lactis as compared with LPS-stimulated PBMC.

\section{Induction of CD25 Expression in PBMC by Cell-Free Supernatants of Probiotic and LAB Strains}

The CD25 expression in PBMC stimulated with cellfree extracts of each probiotic and LAB strains of the 17 bacteria, RPMI 1640 (control), MRS, and LPS are shown in Figures 6a and b. Results indicate that none of the cell-free extracts induced increased expression of $\mathrm{CD}^{+} \mathrm{CD} 4^{+} \mathrm{CD} 25^{+} \mathrm{T}$ lymphocytes in PBMC more than LPS-induced cells. Cell-free extracts of 3 strains of $B i$ fidobacterium (BL1941, BB12, and BB99) and 2 strains of Lactobacillus (Lb. salivarius 5248 and Lb. paracasei 292) showed similar CD25 expression to that of LPS induction, with approximately 1.6-fold more than unstimulated PBMC. Moreover, compared with untreated PBMC, the percentages of $\mathrm{CD}^{+}{ }^{+} \mathrm{CD} 4^{+} \mathrm{CD} 25^{+} \mathrm{T}$ cells were found substantially more in PBMC induced with cell-free supernatants of $L b$. casei 290 followed by $L b$. acidophilus 388, Lb. acidophilus 2401, Lc. lactis R704, and Lb. rhamnosus 5434 .

\section{DISCUSSION}

The current study demonstrated differential cytokine profile for cell-surface components and cell-free culture supernatants of 17 probiotic and LAB strains consisting of Lactobacillus, Bifidobacterium, Streptocococcus, and Lactococcus species after coculturing with buffy coatderived PBMC from healthy donors. The cell-surface components obtained from sonication of probiotic and $\mathrm{LAB}$ strains led to increased production of pro- and antiinflammatory cytokines by PBMC, suggesting the importance of bacterial cell-surface structures in immuno-stimulatory activities. The initial findings from part of an ongoing study (data not shown) and previous research done in our laboratory, suggest that strain differences do exist in cytokine production when PBMC are stimulated with live strains (Donkor et al., 2012). Similarly, in the present study, magnitude of responses for each cytokine released from PBMC varied depending on the type of stimulant, such as metabolites and cell-surface components of individual strain that may be attributed to strain specificity. These findings add 

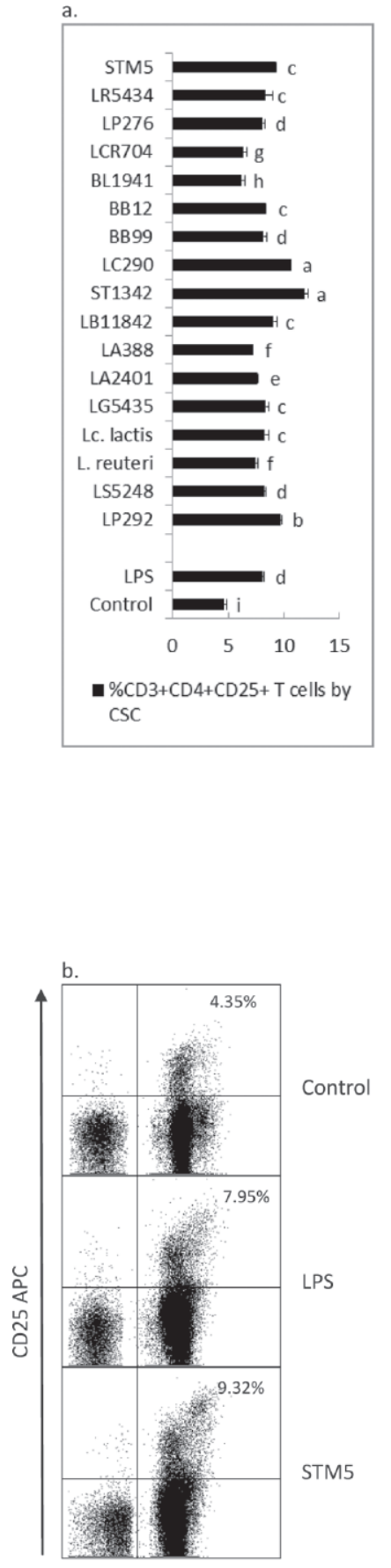

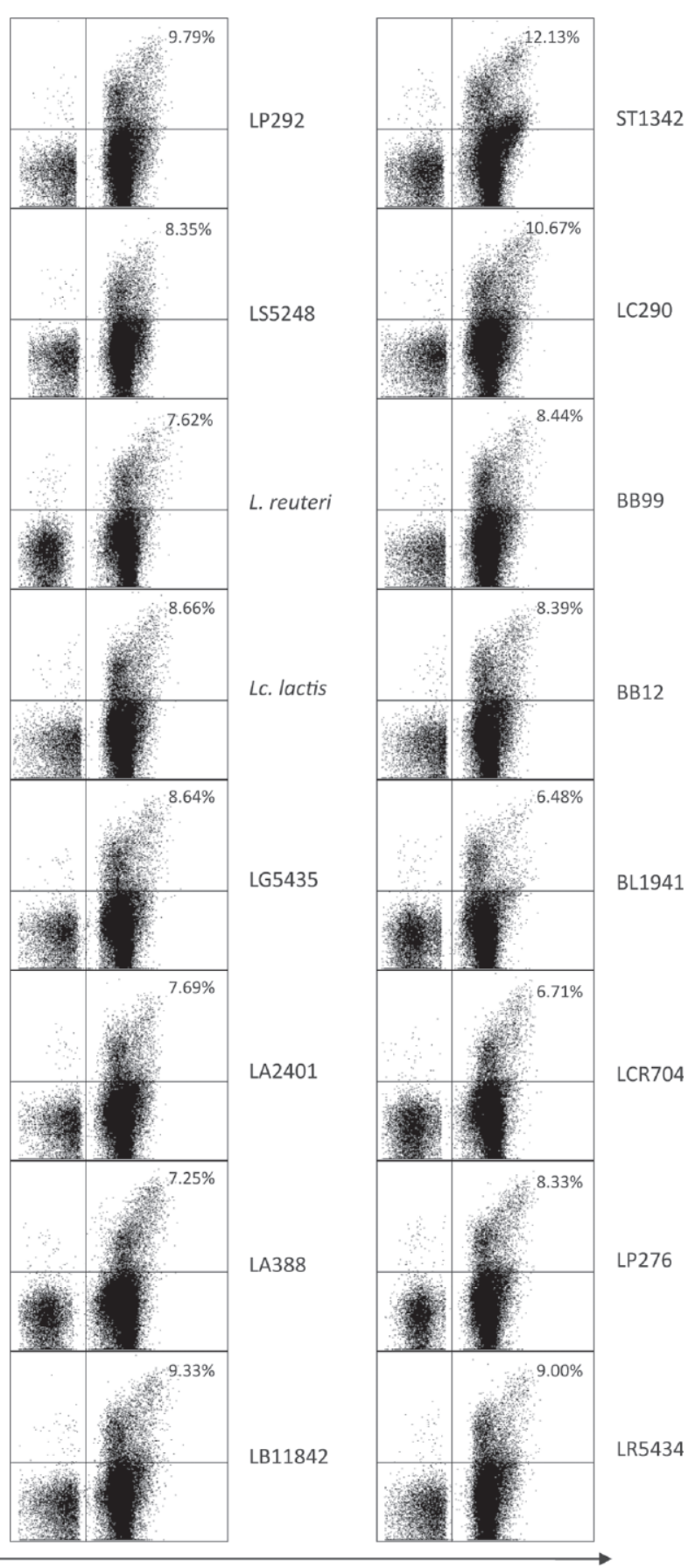

CD4 FITC

Figure 5. Expression of activation marker CD25 by lymphocytes in response to cell-surface components of 17 lactic acid bacterial strains. Peripheral blood mononuclear cells (PBMC) were cultured with cell-surface components of 17 lactic acid bacterial strains [Lactobacillus casei 290 (LC290), Bifidobacterium breve BB99 (BB99), Bifidobacterium animalis ssp. lactis BB12 (BB12), Bifidobacterium longum 1941 (BL1941), Lactococcus lactis R704 (LCR704), Lactobacillus plantarum 276 (LP276), Lactobacillus rhamnosus 5434 (LR5434), Streptococcus thermophilus M5 (STM5), Lactobacillus paracasei 292 (LP292), Lactobacillus salivarius 5248 (LS5248), Lactobacillus reuteri, Lc. lactis, Lb. rhamnosus G5435 (LG5435), Lactobacillus acidophilus 2401 (LA2401), Lb. acidophilus 388 (LA388), Lactobacillus delbrueckii ssp. bulgaricus 11842 (LB11842), and S. thermophilus 1342 (ST1342)] for $96 \mathrm{~h}$ and evaluated for the expression of CD25 on T lymphocytes. Data were acquired using fluorescenceactivated cell sorter (FACS) Calibur and analyzed by flowlogic software. (a) The percentages of CD3 ${ }^{+} \mathrm{CD} 4^{+} \mathrm{CD} 25^{+}$cells were assessed after extracellular staining of $96 \mathrm{~h}$ of coculture. Plots were gated on CD3. Significant differences among samples were established using the least significant difference test. Means in the same graphic representation with different letters $(\mathrm{a}-\mathrm{i})$ are significantly different $(P<0.05)$. (b) Representative FACS plots for cultures described in (a); one representative experiment is shown of 3 different donors and from 17 cell-free culture samples of live strains used in these experiments. 

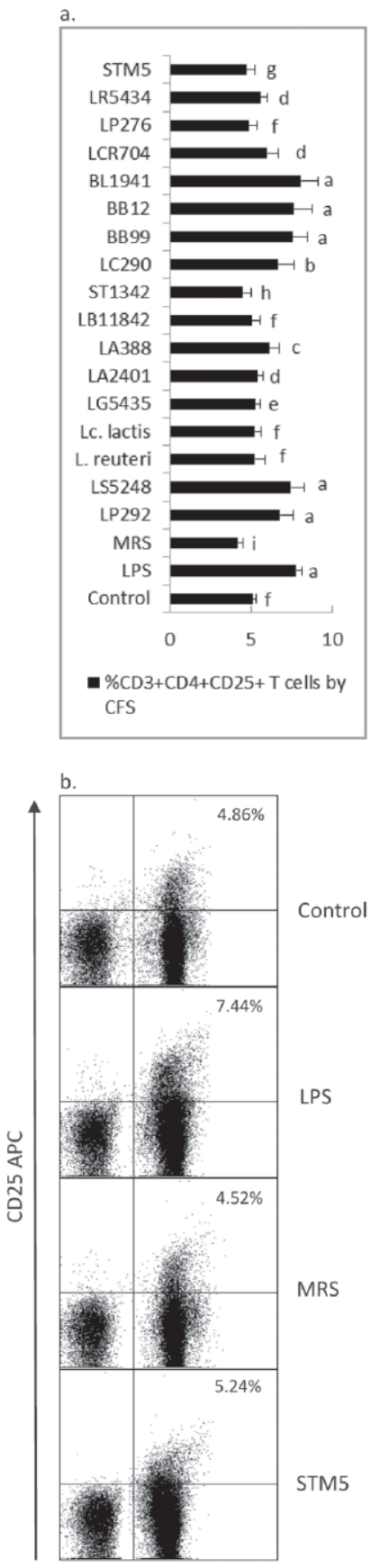

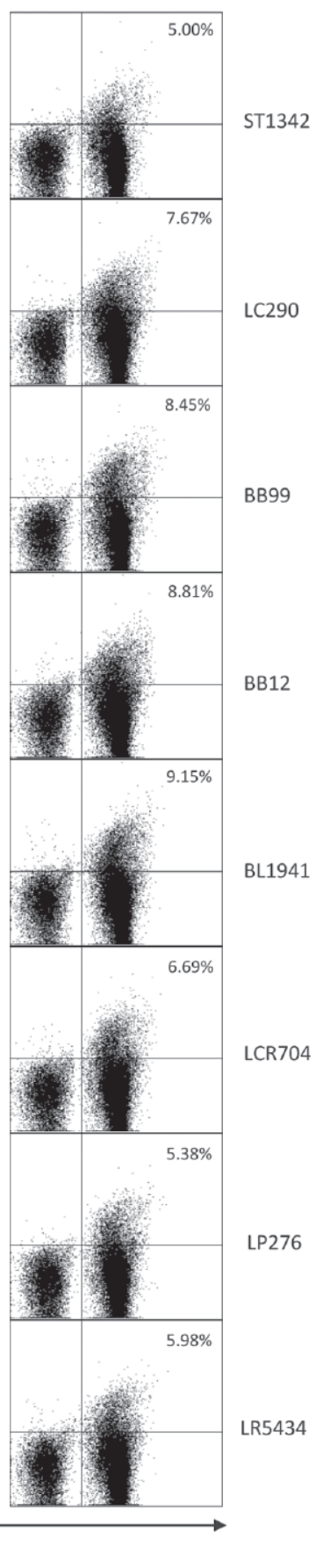

Figure 6. Expression of activation marker CD25 by lymphocytes in response to cell-free culture supernatants of 17 lactic acid bacterial strains. Peripheral blood mononuclear cells (PBMC) were cultured with cell-free culture supernatants of 17 lactic acid bacterial strains Lactobacillus casei 290 (LC290), Bifidobacterium breve BB99 (BB99), Bifidobacterium animalis ssp. lactis BB12 (BB12), Bifidobacterium longum 1941 (BL1941), Lactococcus lactis R704 (LCR704), Lactobacillus plantarum 276 (LP276), Lactobacillus rhamnosus 5434 (LR5434), Streptococcus thermophilus M5 (STM5), Lactobacillus paracasei 292 (LP292), Lactobacillus salivarius 5248 (LS5248), Lactobacillus reuteri, Lc. lactis, Lb. rhamnosus G5435 (LG5435), Lactobacillus acidophilus 2401 (LA2401), Lb. acidophilus 388 (LA388), Lactobacillus delbrueckii ssp. bulgaricus 11842 (LB11842), and S. thermophilus 1342 (ST1342)] for $96 \mathrm{~h}$ and evaluated for the expression of CD25 on T lymphocytes. de Man, Rogosa, and Sharpe (MRS) media without any inoculation was run as another negative control. Data were acquired using fluorescence-activated cell sorter (FACS) Calibur and analyzed by flowlogic software. (a) The percentages of $\mathrm{CD} 3^{+} \mathrm{CD} 4{ }^{+} \mathrm{CD} 25^{+}$cells were assessed after extracellular staining of $96 \mathrm{~h}$ of coculture. Plots were gated on CD3. Significant differences among samples were established using the least significant difference test. Means in the same graphic representation with different letters $(\mathrm{a}-\mathrm{i})$ are significantly different $(P<0.05)$. (b) Representative FACS plots for cultures described in (a); one representative experiment is shown of 3 different donors and from 17 cell-free culture samples of live strains used in these experiments. 
important information for the screening of probiotic and LAB strains for future clinical trials and their use as a food supplement for the treatment of immune-mediated diseases such as allergies and autoimmune disorders.

The stimulation of PBMC with cell-surface structures demonstrated a similar pattern to that obtained from stimulation of PBMC with live strains (data not shown). Our findings show that cell-surface components of probiotic bacteria are critical and play a major role in stimulating immune responses. Some of the variations in cytokine responses from live versus cell-surface structures of these bacteria may be due to differences in the efficiency of sonication method among strains. Of note, the variations from live versus cell surface fractions are unlikely due to donor variations, because the stimulation experiments were performed in parallel using PBMC from same donors and supernatants were collected simultaneously and stored at $-20^{\circ} \mathrm{C}$ for cytokine analysis. The differences for some cytokine responses, establishes that compounds other than cell metabolites or associated with cell surfaces could have been involved the immuno-stimulatory activities of these bacteria. These components might work in combination with other bacterial fragments, metabolites, or structural motifs to interact with the receptors on monocytes to induce optimal cytokine release (Amrouche et al., 2006). We found that TNF- $\alpha$ production was greater when PBMC were stimulated with live population than cell-surface structures or culture-free extracts of probiotic and LAB strains. It has been stated that whole bacterial cells are a more effective stimulus for TNF- $\alpha$ induction than purified cell-surface fractions or peptidoglycans (Timmerman et al., 1993). This shows that different mechanisms of stimulation could work for some cytokine production, such as TNF- $\alpha$ or IFN- $\gamma$, which might require direct cell-cell contact. Similarly, Lb. rhamnosus GG has been shown to exert specific antiapoptotic effects, for which direct contact was needed, through the inhibition of TNF- $\alpha$-stimulated activation of the proapoptotic mitogen-activated protein kinase p38 (Yan et al., 2007). Studies have also shown that some host pathways are modulated by direct contact (Resta-Lenert and Barrett, 2003, 2006; Yan et al., 2007), but factors involved in eliciting the response by cell-cell contact are yet to be identified.

Consistent with a previous report (Medina et al., 2007), our results demonstrate that TNF- $\alpha$ production was induced in comparatively negligible amounts by cell-surface structures of LAB strains. The production of the TNF- $\alpha$ cytokine in response to bacteria has been related to the tertiary structures of cell-surface proteins and peptidoglycan, which could have been disrupted during extraction procedure by sonication. Prolonged sonication has been reported to affect induction of TNF- $\alpha$ release by monocytes either by modification in tertiary structure or size reduction of macromolecules or both (Timmerman et al., 1993).

Secretion of some cytokines affects the induction of others. For instance, IL-12 is a multifunctional cytokine, described as a maturation factor for cytotoxic T lymphocytes and a stimulatory factor for NK cells, resulting in induction of IFN- $\gamma$ production (BermúdezHumarán et al., 2003). Interferon- $\gamma$ is known to be a major macrophage-activating lymphokine, such as IL-4, IL-5, and IL-10 (Meydani and Ha, 2000; Amrouche et al., 2006). In addition, TNF- $\alpha$ expression in macrophages is regulated by IFN- $\gamma$ through interferon regulatory factor 1 and 8 (Vila-del Sol et al., 2008). Therefore, in the present study, less IFN- $\gamma$ released by monocytes for both samples of cell metabolites and cell-surface structures could be attributed to decreased levels of TNF- $\alpha$.

The cellular components of probiotic organisms have been demonstrated to stimulate monocyte or macrophage in similar fashion as do other gram-positive bacteria or their cell components (Dogi et al., 2010). Some of these fractions have been used in studies to demonstrate relative efficiencies of individual purified components, such as LPS (from E. coli), peptidoglycan (from Staphylococcus aureus), and lipoteichoic acids (from Staphylococcus aureus and Enterococcus faecalis) in the stimulation of PBMC for the production of cytokines, including TNF- $\alpha$, IL-6, and IL-10. Lipopolysaccharide was graded as 100 to 1,000 times more efficient than peptidoglycan, and peptidoglycan was ranked 10 to 100 times more effective than lipoteichoic acids. Moreover, LPS-induced production of proinflammatory cytokines TNF- $\alpha$, IL-6, and IL-10 (Erickson and Hubbard, 2000; Hessle et al., 2005). In line with observations reported in these studies, our data established that LPS is a strong inducer of TNF- $\alpha$, IFN- $\gamma$, and IL-10, but a poor inducer of TGF- $\beta$ and IL-12. Interestingly, a majority of cell-surface components of probiotic and LAB proved to be more efficient than LPS in inducing the production of IL- 2 , IL- 4 , IL-12, and TGF- $\beta$, but the responses for IL-10 and TNF- $\alpha$ were more or less similar for both.

Chen et al. (1999) reported that gram-positive cell walls of the normal intestinal bacteria induce human PBMC to produce TNF- $\alpha$ and IL-10, but not IL-4 or IFN- $\gamma$. However, in our study, crude cell-surface fractions of probiotic and LAB strains induced substantial production of IL-10 and TNF- $\alpha$ and negligible IFN- $\gamma$ (with one exception for LB11842), whereas IL-4 was induced by majority of the samples (range of 4-163 with a median of $34.3 \mathrm{pg} / \mathrm{mL}$ at $72 \mathrm{~h}$ ). The secretion of TNF- $\alpha$ and IL-10 from monocyte-macrophage U937 
cell line treated with purified lipoteichoic acid from probiotic strain $L b$. acidophilus A9 has also been reported in a dose-dependent way (Dogi et al., 2010). Furthermore, other studies reported induction of IL-10 and antiinflammatory properties of cell wall and metabolites of probiotic bacteria (Amrouche et al., 2006; Hoarau et al., 2006; Medina et al., 2007; Jensen et al., 2010). In the current study, spent culture media for the strains of probiotic and lactic acid substantially induced IL-10 but not TNF- $\alpha$ production. These findings suggest that both bacterial metabolites and cell-surface structures are involved in antiinflammatory responses by probiotic and LAB strains through IL-10 secretion; however, proinflammatory immune responses mediated through TNF- $\alpha$ secretion are predominantly directed by bacterial cell-surface structures.

The cell protein fraction of Lc. lactis induced significant $(P<0.05)$ production of IL-12 and IL-2 in our study, in accordance with Bermúdez-Humarán et al. (2003), who demonstrated the secretion of IL-12 by Lc. lactis. This bacterium has been used successfully as live bacterial delivery vector (Bermúdez-Humarán et al., 2011). Moreover, it has the ability to modulate maturation of dendritic cells and is known to elicit innate inflammatory responses (Wells and Mercenier, 2008; Rottiers et al., 2009). Lactic acid bacteria, including Lc. lactis, have established safety profile and generally regarded as safe status through a long history of use in fermented dairy products. The fact that these strains express many antigens, induce different cytokine profiles, and can elicit both systemic and mucosal immunity, make probiotic and LAB strains attractive candidates for the development of mucosal vaccines.

The induction of $\mathrm{CD} 4{ }^{+} \mathrm{CD} 25^{+}$Treg cells after stimulation of PBMC with cell-surface fractions and secreted metabolites of 17 strains of LAB and probiotic bacteria show that the induction of Treg cells appeared to be influenced by cellular surface structures and metabolites of the probiotic and LAB strains, with cell-surface components showing higher induction. The $\mathrm{CD} 4^{+} \mathrm{CD} 25^{+}$Treg cells are involved in maintaining self-tolerance by downregulating immune response to self and nonself antigens (Sakaguchi et al., 1995). For their viability and suppressive function, $\mathrm{CD} 4{ }^{+} \mathrm{CD} 25^{+}$ Treg have shown in vitro to require direct contact of regulatory cells with target cells and secretion of the immuno-regulatory cytokines IL-10, TGF- $\beta$, including small amounts of IL-2 (von Boehmer, 2005; Fantini et al., 2007; Bollyky et al., 2009; Lavasani et al., 2010). This was affirmed in our study, as IL-10, TGF- $\beta$, and IL-2 were released by PBMC treated with probiotic and LAB strains. The trend in induction CD25 expression by cell-surface fractions corresponds to the expression obtained from PBMC stimulated with live strains. It is believed from the results that the cell-surface structures have a primary inductive role in Treg differentiation.

As elimination or decline of $\mathrm{CD} 4{ }^{+} \mathrm{CD} 25^{+}$cells is implicated with enhanced immune responses to nonself and self antigens (Sakaguchi et al., 1995), an increased number of regulatory cells by probiotic induction could help in controlling autoimmune diseases. In this respect, strains of probiotic and LAB, including $S$. thermophilus 1342, Lb. casei 290, Lb paracasei 292, S. thermophilus M5, Lb. delbrueckii ssp. bulgaricus 11842 , B. lactis BB12, Lb. rhamnosus G5434, Lb. rhamnosus 5434, Lc. lactis, Bifidobacterium spp. (BL1941, BB12 and BB99), and $L b$. salivarius 5248 , demonstrating high induction of CD25 expression could be potential candidates in maintaining self-tolerance and, in turn, help in the treatment of autoimmune diseases. Prior to in vivo studies in our laboratory, the current paper focused on the differences and variations in immune responses of probiotic strains and studied in detail the in vitro or ex vivo characteristics and behavior of these strains on human PBMC. These findings will serve as precursor for further studies on animal model to validate their specific clinical applications.

\section{ACKNOWLEDGMENTS}

The research was funded by Victoria University-Australian Postgraduate Research Award. We are grateful for Australian Red Cross Blood Services for their supply of blood products and we acknowledge the technical support granted by Burnet Institute.

\section{REFERENCES}

Amrouche, T., Y. Boutin, G. Prioult, and I. Fliss. 2006. Effects of bifidobacterial cytoplasm, cell wall and exopolysaccharide on mouse lymphocyte proliferation and cytokine production. Int. Dairy J. 16:70-80.

Asseman, C., S. Mauze, M. W. Leach, R. L. Coffman, and F. Powrie. 1999. An essential role for interleukin 10 in the function of regulatory $\mathrm{T}$ cells that inhibit intestinal inflammation. J. Exp. Med. 190:995-1004.

Bermúdez-Humarán, L. G., P. Kharrat, J. M. Chatel, and P. Langella. 2011. Lactococci and lactobacilli as mucosal delivery vectors for therapeutic proteins and DNA vaccines. Microb. Cell Fact. 10(Suppl. 1):S4.

Bermúdez-Humarán, L. G., P. Langella, N. G. Cortes-Perez, A. Gruss, R. S. Tamez-Guerra, S. C. Oliveira, O. Saucedo-Cardenas, R. Montes de Oca-Luna, and Y. Le Loir. 2003. Intranasal immunization with recombinant Lactococcus lactis secreting murine interleukin-12 enhances antigen-specific Th1 cytokine production. Infect. Immun. 71:1887-1896.

Bollyky, P. L., B. A. Falk, S. A. Long, A. Preisinger, K. R. Braun, R. P. Wu, S. P. Evanko, J. H. Buckner, T. N. Wight, and G. T. Nepom. 2009. CD44 costimulation promotes FoxP3 + regulatory $\mathrm{T}$ cell persistence and function via production of IL-2, IL-10, and TGF- $\beta$. J. Immunol. 183:2232-2241. 
Caballero-Franco, C., K. Keller, C. De Simone, and K. Chadee. 2007. The VSL\#3 probiotic formula induces mucin gene expression and secretion in colonic epithelial cells. Am. J. Physiol. Gastrointest. Liver Physiol. 292:G315-G322.

Chen, T., P. Isomäki, M. Rimpiläinen, and P. Toivanen. 1999. Human cytokine responses induced by Gram-positive cell walls of normal intestinal microbiota. Clin. Exp. Immunol. 118:261-267.

Clancy, R. 2003. Immunobiotics and the probiotic evolution. FEMS Immunol. Med. Microbiol. 38:9-12.

Dogi, C. A., F. Weill, and G. Perdigón. 2010. Immune response of nonpathogenic $\operatorname{Gram}(+)$ and $\operatorname{Gram}(-)$ bacteria in inductive sites of the intestinal mucosa. Study of the pathway of signaling involved. Immunobiology 215:60-69.

Donkor, O. N., M. Ravikumar, O. Proudfoot, S. L. Day, V. Apostolopoulos, G. Paukovics, T. Vasiljevic, S. L. Nutt, and H. Gill. 2012. Cytokine profile and induction of $\mathrm{T}$ helper type 17 and regulatory $\mathrm{T}$ cells by human peripheral mononuclear cells after microbial exposure. Clin. Exp. Immunol. 167:282-295.

Erickson, K. L., and N. E. Hubbard. 2000. Probiotic immunomodulation in health and disease. J. Nutr. 130(Suppl.):403S-409S.

Fantini, M. C., S. Dominitzki, A. Rizzo, M. F. Neurath, and C. Becker. 2007. In vitro generation of CD4+ CD25+ regulatory cells from murine naive T cells. Nat. Protoc. 2:1789-1794.

Hessle, C. C., B. Andersson, and A. E. Wold. 2005. Gram-positive and Gram-negative bacteria elicit different patterns of pro-inflammatory cytokines in human monocytes. Cytokine 30:311-318.

Hoarau, C., C. Lagaraine, L. Martin, F. Velge-Roussel, and Y. Lebranchu. 2006. Supernatant of Bifidobacterium breve induces dendritic cell maturation, activation, and survival through a Toll-like receptor 2 pathway. J. Allergy Clin. Immunol. 117:696-702.

Isolauri, E. 2004. The role of probiotics in paediatrics. Curr. Paediatr. 14:104-109.

Jensen, G. S., K. F. Benson, S. G. Carter, and J. R. Endres. 2010. GanedenBC30 ${ }^{\mathrm{TM}}$ cell wall and metabolites: Anti-inflammatory and immune modulating effects in vitro. BMC Immunol. 11:15.

Kaji, R., J. Kiyoshima-Shibata, M. Nagaoka, M. Nanno, and K. Shida. 2010. Bacterial teichoic acids reverse predominant IL-12 production induced by certain Lactobacillus strains into predominant IL-10 production via TLR2-dependent ERK activation in macrophages. J. Immunol. 184:3505-3513.

Lammers, K. M., P. Brigidi, B. Vitali, P. Gionchetti, F. Rizzello, E. Caramelli, D. Matteuzzi, and M. Campieri. 2003. Immunomodulatory effects of probiotic bacteria DNA: IL-1 and IL-10 response in human peripheral blood mononuclear cells. FEMS Immunol. Med. Microbiol. 38:165-172.

Lavasani, S., B. Dzhambazov, M. Nouri, F. Fåk, S. Buske, G. Molin, H. Thorlacius, J. Alenfall, B. Jeppsson, and B. Weström. 2010. A novel probiotic mixture exerts a therapeutic effect on experimental autoimmune encephalomyelitis mediated by IL-10 producing regulatory T cells. PLoS ONE 5:e9009.

Matsumoto, S., T. Hara, T. Hori, K. Mitsuyama, M. Nagaoka, N. Tomiyasu, A. Suzuki, and M. Sata. 2005. Probiotic Lactobacillusinduced improvement in murine chronic inflammatory bowel disease is associated with the down-regulation of pro-inflammatory cytokines in lamina propria mononuclear cells. Clin. Exp. Immunol. 140:417-426.

Matsumoto, S., T. Hara, M. Nagaoka, A. Mike, K. Mitsuyama, T. Sako, M. Yamamoto, S. Kado, and T. Takada. 2009. A component of polysaccharide peptidoglycan complex on Lactobacillus induced an improvement of murine model of inflammatory bowel disease and colitis-associated cancer. Immunology 128:e170-e180.

Mattar, A. F., D. H. Teitelbaum, R. A. Drongowski, F. Yongyi, C. M. Harmon, and A. G. Coran. 2002. Probiotics up-regulate MUC-2 mucin gene expression in a Caco-2 cell-culture model. Pediatr. Surg. Int. 18:586-590.

McHugh, R. S., E. M. Shevach, and A. M. Thornton. 2001. Control of organ-specific autoimmunity by immunoregulatory $\mathrm{CD} 4^{+} \mathrm{CD} 25^{+} \mathrm{T}$ cells. Microbes Infect. 3:919-927.

McHugh, R. S., M. J. Whitters, C. A. Piccirillo, D. A. Young, E. M. Shevach, M. Collins, and M. C. Byrne. 2002. CD $4^{+}$CD $25^{+}$
Immunoregulatory $\mathrm{T}$ Cells: Gene expression analysis reveals a functional role for the glucocorticoid-induced TNF receptor. Immunity 16:311-323.

Medina, M., E. Izquierdo, S. Ennahar, and Y. Sanz. 2007. Differential immunomodulatory properties of Bifidobacterium longum strains: Relevance to probiotic selection and clinical applications. Clin. Exp. Immunol. 150:531-538.

Meydani, S. N., and W. K. Ha. 2000. Immunological effects of yogurt. Clin. Nutr. 71:861-872.

National Health and Medical Research Council. 2007. National Statement on Ethical Conduct in Human Research (2007) - Updated December 2013. The National Health and Medical Research Council, the Australian Research Council and the Australian ViceChancellors' Committee, Commonwealth of Australia, Canberra. Accessed Feb. 20, 2014. http://www.nhmrc.gov.au/guidelines/ publications/e72.

Resta-Lenert, S., and K. E. Barrett. 2003. Live probiotics protect intestinal epithelial cells from the effects of infection with enteroinvasive Escherichia coli (EIEC). Gut 52:988-997.

Resta-Lenert, S., and K. E. Barrett. 2006. Probiotics and commensals reverse TNF- $\alpha$ - and IFN- $\gamma$-induced dysfunction in human intestinal epithelial cells. Gastroenterology 130:731-746.

Rottiers, P., T. De Smedt, and L. Steidler. 2009. Modulation of gutassociated lymphoid tissue functions with genetically modified Lactococcus lactis. Int. Rev. Immunol. 28:465-486.

Ryan, K. A., A. M. O'Hara, J. P. Van Pijkeren, F. P. Douillard, and P. W. O'Toole. 2009. Lactobacillus salivarius modulates cytokine induction and virulence factor gene expression in Helicobacter pylori. J. Med. Microbiol. 58:996-1005.

Sakaguchi, S. 2005. Naturally arising Foxp3-expressing CD25 ${ }^{+} \mathrm{CD} 4^{+}$ regulatory $\mathrm{T}$ cells in immunological tolerance to self and non-self. Nat. Immunol. 6:345-352.

Sakaguchi, S., N. Sakaguchi, M. Asano, M. Itoh, and M. Toda. 1995. Immunologic self-tolerance maintained by activated $\mathrm{T}$ cells expressing IL-2 receptor $\alpha$-chains (CD25): Breakdown of a single mechanism of self- tolerance causes various autoimmune diseases. J. Immunol. 155:1151-1164.

Seddon, B., and D. Mason. 1999. Regulatory T cells in the control of autoimmunity: The essential role of transforming growth factor $\beta$ and interleukin 4 in the prevention of autoimmune thyroiditis in rats by peripheral $\mathrm{CD} 4^{+} \mathrm{CD} 45 \mathrm{RC}^{-}$cells and $\mathrm{CD} 4^{+} \mathrm{CD} 8^{-}$thymocytes. J. Exp. Med. 189:279-288.

Shida, K., J. Kiyoshima-Shibata, M. Nagaoka, K. Watanabe, and M. Nanno. 2006. Induction of interleukin-12 by Lactobacillus strains having a rigid cell wall resistant to intracellular digestion. J. Dairy Sci. 89:3306-3317.

Suzuki, C., H. Kimoto-Nira, M. Kobayashi, M. Nomura, K. Sasaki, and K. Mizumachi. 2008. Immunomodulatory and cytotoxic effects of various Lactococcus strains on the murine macrophage cell line J774.1. Int. J. Food Microbiol. 123:159-165.

Timmerman, C. P., E. Mattsson, L. Martinez-Martinez, L. De Graaf, J. A. G. Van Strijp, H. A. Verbrugh, J. Verhoef, and A. Fleer. 1993. Induction of release of tumor necrosis factor from human monocytes by staphylococci and staphylococcal peptidoglycans. Infect. Immun. 61:4167-4172.

Underhill, D. M. 2003. Toll-like receptors: Networking for success. Eur. J. Immunol. 33:1767-1775.

Van Niel, C. W., C. Feudtner, M. M. Garrison, and D. A. Christakis. 2002. Lactobacillus therapy for acute infectious diarrhea in children: A meta-analysis. Pediatrics 109:678-684.

Vila-del Sol, V., C. Punzón, and M. Fresno. 2008. IFN- - -induced TNF- $\alpha$ expression is regulated by interferon regulatory factors 1 and 8 in mouse macrophages. J. Immunol. 181:4461-4470.

von Boehmer, H. 2005. Mechanisms of suppression by suppressor $\mathrm{T}$ cells. Nat. Immunol. 6:338-344.

Wang, J. E., M. K. Dahle, M. McDonald, S. J. Foster, A. O. Aasen, and C. Thiemermann. 2003. Peptidoglycan and lipoteichoic acid in gram-positive bacterial sepsis: Receptors, signal transduction, biological effects, and synergism. Shock 20:402-414. 
Wells, J. M., and A. Mercenier. 2008. Mucosal delivery of therapeutic and prophylactic molecules using lactic acid bacteria. Nat. Rev. Microbiol. 6:349-362.

Wickens, K., P. N. Black, T. V. Stanley, E. Mitchell, P. Fitzharris, G. W. Tannock, G. Purdie, and J. Crane. 2008. A differential effect of 2 probiotics in the prevention of eczema and atopy: A double- blind, randomized, placebo-controlled trial. J. Allergy Clin. Immunol. 122:788-794.

Yan, F., H. Cao, T. L. Cover, R. Whitehead, M. K. Washington, and D. B. Polk. 2007. Soluble proteins produced by probiotic bacteria regulate intestinal epithelial cell survival and growth. Gastroenterology 132:562-575. 